\title{
Interns and Infidels: \\ The Transformation of Work and Citizenship in Turkey and the United States under Neo-liberalism ${ }^{1}$
}

\author{
Kaan Agartan, Framingham State University, USA \\ Cedric de Leon, Providence College, USA
}

\begin{abstract}
How do the dispossessed remain governable under economic insecurity? What explains the persistence of work as a prerequisite to social rights in a time when fewer formal jobs exist? Drawing on a comparison of Turkey and the United States since 1980, we demonstrate that the neo-liberal state deploys different versions of the "work-citizenship nexus" to manage both the shrinking minority who enjoy the benefits of full citizenship and the rest who struggle to attain the rights and privileges of the formally employed. We find that neo-liberal state practices comprise a dual movement. On the one hand, the state in both countries reorients itself toward the market in welfare provision and the regulation of labour relations, capitalising on precarious work structures to bring their populations into the fold of neo-liberal governance. On the other hand, the state directly intervenes in disparate ways to manage those who cannot make it in the market. While the American state uses tactics of mass incarceration and deportation, the Turkish state opts for a blend of social conservatism and authoritarianism. This dual movement of reorientation and direct intervention results in what we call "tiered citizenship regimes" that facilitate the management of the population in each case.
\end{abstract}

\section{KEYWORDS}

neo-liberalism; work; social citizenship; governmentality; Turkey; United States

\section{Introduction}

Macro-historical accounts typically frame neo-liberalism as an economic doctrine that has exploded the Fordist mode of capital accumulation and in doing so deepened economic inequality. Thus, Harvey (2007: 33-35) writes that neo-liberalism has dispossessed the poor and working class, and redistributed wealth upwards through privatisation, regressive taxation and international loans, among other tactics. Macro-historical analysis, however, is largely

\footnotetext{
1 The authors would like to thank Kevan Harris, Brendan McQuade, Jessica Dianne Cook, Michael Rodriguez-Muñiz, Diana Graizbord, Aisalkyn Botoeva, and the anonymous reviewers for their helpful comments on earlier drafts of this paper.
} 
silent on an important puzzle about the neo-liberal order: how do the dispossessed remain governable under these conditions?

Scholars of governmentality have sought to fill that gap by moving beyond neoliberalism as an economic doctrine, and examining it instead as a technology for managing the population. Many in this camp hold that citizenship is a means by which the state and other actors render disgruntled individuals and collectivities more docile. However, there are at least three problems with the literature. First, it side-lines neo-liberalism's economic implications, especially for the transformation of work, as a vehicle for the inculcation of docility. Collins (2013: 4), for instance, warns that research on biosecurity has largely sidestepped questions of job security. Second, we find that discursive regimes by themselves do not explain the urgency with which marginalised subjects struggle to succeed in the neo-liberal order (Lordon, 2010). The neo-liberal transformation of work has meant that full social citizenship ceases to be a right and becomes instead a cut-throat competitive process. Third, the literature deemphasises what some have called the "authoritarian" turn in state practices since the 1970s, which manages uncooperative subjects who either reject neo-liberalism or lack the social and cultural capital to participate in it (Hall et al., 1978; Poulantzas, 1978). Failing to acknowledge this nuance leads the governmentality literature to ignore how the "Workfare State" operates to stabilise market-based patterns of domination (Jessop, 2002).

Focusing in this paper on the relationship between the transformation of work and social citizenship, we seek to synthesise macro-historical approaches and the literature on governmentality with the Marxist literature on state authoritarianism to examine neoliberalisation in Turkey and the United States (US). As we demonstrate below, the transformation of work under neo-liberalism is experienced in a parallel fashion yet with different manifestations in these two countries. It is within this framework that we interpret neo-liberalism not simply as the transformation of capital accumulation, but also of the conditions in which one makes claims to full citizenship.

Under Fordism, ${ }^{2}$ people were citizens provided that they worked in the formal wage sector. The social safety net was linked to work: one "paid into" unemployment insurance, social security and other such programmes during one's working life, and was therefore entitled to draw on those funds in lean times and old age. Under neo-liberalism, stable, wellpaying, guaranteed formal-sector employment remains a prerequisite to social citizenship rights, yet fewer and fewer such jobs exist. Moreover, the state reorients itself toward the market in terms of welfare provision and the regulation of labour relations, leaving wage earners to compete for unregulated, laborious, insecure, and poorly paid private-sector jobs. Alongside this market reorientation, the neo-liberal state directly intervenes to manage those

2 Our comparison of Fordism and neo-liberalism does not focus on the assumed success or failure of the two regimes in serving large segments of the population. We are well aware that, despite what it claimed, Fordism did not serve the vast informal economy in Turkey, while the racial contradictions of the New Deal excluded people of colour from social citizenship in the United States. Nor could neo-liberalism uphold its claims, that the creative and productive capacity of the individual in the market could trump the state in delivering social justice. The story we tell in this paper is about the big paradigmatic shift in the pretensions of governance under these two regimes in capitalism.

Global Labour Journal, 2016, 7(3), Page 221 
who are either unable or unwilling to submit to the whip of the market. For these groups who have no inclination to join the ranks of the "precariat" (Standing, 2011), the neo-liberal state innovates methods ranging from incarceration and deportation to various forms of repression.

In this paper we aim to shed light on this seemingly paradoxical advance of the neoliberal state - unleashing market actors to take over the provision of the means of social reproduction on the one hand, and intervening to contain the resistance and uncertainty resulting from marketisation on the other. The Turkish and American experiences of this dual movement of the neo-liberal state result in what we call "tiered citizenship regimes" 3 that facilitate the management of their populations by symbolically and materially privileging sectors that bow to the coercion of the market, and stigmatising and punishing sectors that do not or cannot.

As we will discuss later, our choice of cases is by no means accidental. Turkey, our case for the Global South, offers unique insight into the interventionist mode of the neo-liberal state because market relations are institutionalised, often through direct intervention in labour regulation and social welfare policies, as well as the repressive and socially conservative practices of the government. Consequently, newly groomed working and middle classes enjoy privileged access to full social citizenship, while others are cast out as "infidels". By contrast, in the United States, our case for the Global North, the promise of full citizenship as a member of the middle class is felt most at the frontiers of the emerging gig economy, where the unemployed must now go in the hope that successive internships and odd jobs will convert into permanent full-time jobs.

\section{Work, Citizenship and Governance}

Despite immense academic interest, the question of governance in the face of growing inequality and dispossession has been addressed within what we see as discreet inquiry domains. While the literature on the transformation of work does not address the governance of wage-earners through social citizenship, the literature on new conceptualisations of citizenship remains indifferent to organisational changes in the world of work. In what follows, we point out the provincial character of these separate areas of inquiry, and offer a synthesis to address the question of maintaining social order in the face of growing disfranchisement.

\section{Transformation of work under neo-liberalism}

Within the growing sphere of neo-liberalism studies, there is no shortage of interest in the transformation of work. The literature addresses a wide array of issues, including: the impact of de-industrialisation on the rise of the flexible worker (Standing, 1999); technological

\footnotetext{
${ }^{3}$ These different tiered citizenship regimes are distinct from what Esping-Andersen (1990) has called "conservative" welfare states in Germany and elsewhere, in which economic resources are redistributed differently based on one's occupational status in the formal wage sector. In our account, the neo-liberal state presides over an intensifying binary in the informal sector between the precariat on the one hand and unruly surplus populations on the other.
} 
advances and new forms of work organisation (Smith, 1997; Beck, 2000; Head, 2003); the rise of non-standard employment patterns and wage systems (Tilly, 1996; Kalleberg, 2011); the changing meanings of work in the face of growing exhaustion and alienation (Schor, 1993; Sennett, 2000); the swelling ranks of the working poor (MacLeod, 2008; Juravich, 2009; Ehrenreich, 2011); and the emergence of "white-collar sweatshops" (Fraser, 2002). Studies on the Global South in particular address issues such as: subcontracting and export processing zones (Heller, 2000; Sainz, 2000); labour control in the informal economy (Hanser, 2007; Rocha, 2004; Roy, 2007); and gendered patterns of home-based production (Gopal, 2007; Dedeoglu, 2008; Beneria, 2010).

Despite its extensive scope, the literature is often silent on the implications of the transformation of work for broader questions of governance. Two notable exceptions bear mention, however. Bob Jessop (2002) focuses on the metamorphosis of the welfare state into a new form in which social policy is subordinated to economic policy, resulting in downward pressure on the social wage. Similarly, Colin Crouch's (2011) approach to financialisation as a disciplinary mechanism that compels low- and middle-income American workers to adapt to the uncertainties of the neo-liberal economy provides a useful context for our discussion.

Incorporating the wider angle that Jessop and Crouch provide, we examine the ways through which different strategies and modes of governance in the world of work take shape in tiered citizenship regimes for stabilising, normalising and disguising relations of social domination. This in turn guides us toward the literature on citizenship and governmentality.

\section{Market citizenship and governmentality}

Recently, scholars have turned their attention to a market-based notion of citizenship. This holds that one's rights ought to be commensurate with one's success in the market, and that citizenship entails only the protection of the individual pursuit of self-interest (Somers, 2001; Root, 2007). Though the concept of "market citizenship" helps us to understand how citizenship is increasingly commodified, it stops short of explaining how those who cannot make it in the market, are governed by the neo-liberal state. This limitation can be overcome with the Foucauldian concept of governmentality, which centres on the discourse and exercise of freedom, citizenship and rights as technologies of power. In this tradition, citizenship becomes a mechanism through which the state convinces people to regulate their own conduct (Foucault, 1991 [1979]). Thus, for Rose (1999, 2007), the discourse and practice of freedom entails a code of conduct that serves as a checklist of civility and normality. A different take is Aihwa Ong's (1999: 217, 2006: 5-7) concept of flexible citizenship, according to which states make divergent investments in different sectors of the population, conferring the privileges of citizenship on "one gender over the other, and in certain kinds of human skills, talents, and ethnicities".

\section{Towards a new approach: the work-citizenship nexus and the authoritarian turn}

To the extent that scholars of governmentality address work, they focus principally on the discourse of work as a requirement of citizenship that cultivates a culture of self-blame 
among the poor in a system where there is simply not enough work to go around. Yet the approach fails to highlight both the ways through which the transformation of work itself produces a more docile population, and the authoritarian practices of the neo-liberal state visà-vis those who are unable or unwilling to brave the emerging economy.

In his work on post-apartheid South Africa, Franco Barchiesi (2011) points out that the capacity of formal-sector work to act as a source of social citizenship is in steady decline for many people, who are left fully responsible for their own predicament. Policies such as

"reskilling", "self-activation", "marketability", and "workfare" then "operate at a 'micropolitical' level as institutional injunctions and pedagogical devices to promote virtuous citizenship intended as individual spirit of enterprise” (Barchiesi, 2011: 10).

The Marxist literature on state authoritarianism theorises direct state intervention into sectors of the population that are either socially excluded from the market or mutinous with respect to neo-liberalism. For example, Stuart Hall and his associates (1978: 218) argued that in 1970s Britain the state employed the fictive epidemic of mugging in urban centres to justify an authoritarian state response to the crisis of Labourist capitalism, signalled by the mass uprisings of the 1960s. Poulantzas (1978: 204, 220) similarly observed the emergence of "authoritarian statism" in the 1970 s, which he defined as "intensified state control over every sphere of socio-economic life combined with radical decline of the institutions of political democracy and with draconian and multiform curtailment of so-called 'formal' liberties" (emphasis in the original).

In this paper, we bring together Barchiesi, Hall and Poulantzas to theorise the practices of the neo-liberal state in Turkey and the US. First, we argue that far from dispensing with the Fordist work requirement for access to social citizenship rights, the neo-liberal state in fact applies it relentlessly so that only a shrinking minority can still claim social benefits. Whether by laying the legal groundwork for precarisation (as in Turkey), or by giving market actors licence to precaritise further (as in the US), the neo-liberal state reorients itself toward the market in welfare provision and labour regulation. But secondly, we point out that for those who are unable or unwilling to participate in their own subordination, the neo-liberal state forcefully intercedes with other strategies, ranging from adopting a conservative and religious rhetoric to demonising collective protest. It is the variations of this simultaneous reorientation and intervention of the neo-liberal state in Turkey and the US that guide our approach to theorising how contemporary changes in the world of work manifest themselves in "tiered citizenship regimes" and become effective strategies of governance in the face of deepening social inequality.

\section{The Logic of Comparison}

But why compare the United States and Turkey? The two cases are undoubtedly different, yet their differences comprise a strength for the analysis of the relationship between work, citizenship and governmentality. Our choice of the two countries is not arbitrary as each offers unique insights into the dual nature of the neo-liberal state in the Global North and Global South. They demonstrate how the transformation of work in each case engenders 
particular strategy constellations to produce a tiered citizenship regime that renders a given population governable. The analysis below will demonstrate that the Turkish and American experiences reveal clearly the variety of ways through which the neo-liberal state manages its population utilising the work-citizenship relation.

The US, as the centre and main engine of global capitalism, best exemplifies how the livelihoods of a growing number of able-bodied unemployed or underemployed workers in the Global North are becoming more dependent on the market status of their jobs under neoliberalism. The analysis of the US suggests that workers in the Global North who possess devalued skill sets are exposed to an increasing risk of unemployment or precarious jobs (Andersen and Jensen, 2002: 4), whereas secure and stable jobs that have social benefits are being reserved for the shrinking minority of core employees (Standing, 2009: 41). Here, the reorientation of the neo-liberal state towards unfettered market forces to determine who is rewarded and who is disciplined can be observed unambiguously.

On the other hand, Turkey's private-sector-led industrialisation since the $1980 \mathrm{~s}$ demonstrates how the "bifurcation of the global labour force" (McMichael, 2012: 88) manifests itself in the form of more semi-skilled and unskilled labour concentrating in the Global South. Similar to many emerging economies, Turkey has adopted a subcontractor role for producing low-value, labour-intensive consumer or intermediate goods in buyer-driven commodity markets (Kutlu, 2012). This has deepened insecurity and precariousness in mostly family-owned, export-oriented, small and medium-sized enterprises located in socially conservative regions of the country (Durak, 2011). Turkey's experience with neo-liberalism puts in stark relief the neo-liberal state's advances in constituting a framework of social regulation. This has been achieved mainly by recruiting different sectors of the population to social conservatism, and in garnering ideological support to shore up a new citizenship regime. With its new conservative breed of working and middle classes groomed by the AKP government, along with the new outcasts of the society who are increasingly dependent on government assistance for their survival, Turkey offers a distinct instance of the interventionist character of the neo-liberal state.

Thus a careful comparison of the Turkish and American experiences of the transformation of work helps to understand the development of precarious employment patterns both in the Global North and Global South, and their far-reaching social and political implications. The governability of the dispossessed in the United States is secured primarily through precarious work structures imposed by the market, while the state keeps in the background coercive disciplinary tactics of incarceration and deportation to contain those who are unwilling or unable to fit in. In Turkey a distinct docility is inculcated primarily through the unilateral restructuring of the labour market and a top-down imposition of social conservatism by the neo-liberal state, while market-induced precarity operates in the background.

In the following section we offer a closer examination of these cases with respect to how changes in the world of work help to render their populations governable under a transformed citizenship regime defined by a unique balance of direct state intervention and market reorientation. 


\section{The Transformation of Work and New Citizenship Regimes}

Turkey and the United States have experienced distinct yet related transformative processes in their work structures in the last few decades. In the US, the neo-liberal state has primarily enabled market forces to govern wage earners through the very structure of emerging precarious work patterns. In Turkey, on the other hand, we observe the neo-liberal state in the foreground, creating the conditions for precarisation. The resulting tiered citizenship regimes, which are increasingly in tune with the logic of the market, are accompanied by unique yet complementary authoritarian practices in the background.

\section{The transformation of work in the American economy}

We observe the rise of two types of work that are available to the unemployed and underemployed in the gig economy: unpaid or low-wage internships, and "distributed workforce" jobs in crowdsourcing firms like Uber and TaskRabbit. Novel relations of employment within these types facilitate the management of the American population in a context of high unemployment.

The situation of those actively seeking employment is the first empirical aspect of our notion of tiered citizenship, in which the state continues to shield the shrinking ranks of the gainfully employed from the vicissitudes of the market, while leaving the rest to fend for themselves. According to the Congressional Budget Office, the poorest fifth of American households consumed 54 per cent of social benefits in 1979; today they consume only 36 per cent, while the lion's share goes towards "maintaining the middle class from childhood through retirement" (Appelbaum and Gebeloff, 2012: 1). After welfare reform became law under the Clinton administration, the amount of cash payment to welfare recipients decreased dramatically from $\$ 20.4$ billion in 1996 to $\$ 9.6$ billion in 2011 (Congressional Budget Office, 2011; Appelbaum and Gebeloff, 2012; Luhby, 2012).

In turn, the jobless must negotiate a terrain of low-wage or unpaid, insecure employment due to the state's simultaneous market orientation in the provision of welfare benefits and regulation of labour relations. The effect of this shift in state practices has been to essentially privatise unemployment relief. As an investigative reporter for Businessweek observed of distributive workforce firms, "These companies may be building something significant: a uniquely American safety net for the unemployed or underemployed, who can now have somewhere to turn when they need money" (Stone, 2012). When they arrive in the private sector, the unemployed are organised and managed in various ways: as interns by the promise of a permanent white-collar job and as task rabbits by smartphone apps and the prospect of micro-entrepreneurship.

\section{$\underline{\text { Interns }}$}

The National Association of Colleges and Employers estimates that nearly half of internships are unpaid and that about three-quarters of all college students will have worked in an internship by graduation. This marks a shift in the pervasiveness and character of 
internships: in 1980, only 3 per cent of undergraduates worked as interns. Further, internships were once primarily training programmes, but they now appear to also be used as a source of cheap labour. Tens of thousands of unpaid internships are actually illegal, because many are not proper work-cooperative programmes and must therefore pay the statutory minimum wage (Perlin, 2011).

The primary disciplinary feature of intern work is the hope for a full-time job either with the host employer or with a future employer, who, workers hope, will be impressed with the job experience that internships provide. Of course, this does not always occur. Despite likening internships to "slavery" and having done seven of them in a row, Ivellise Morales, a veteran of seven internships, continued to believe that work experience was the key to her future employment: employers, she says, are "going to care what you've done in the past" (Perlin, 2011; Sachs, 2011; NACE, 2012).

The hope that an internship will convert to a full-time position is animated by at least two factors. The first is youth unemployment, which is at an all-time high of 20 per cent for men and women aged 16 to 24. One indicator of the severity of youth unemployment is "prolonged adolescence": whereas in 1970 approximately 10 per cent of young adults lived at home, the present-day figure is double that. The second factor is the discourse of "human capital", which is pervasive in corporate America. Coined by Gary Becker, human capital theory suggests that an investment like a college education or internship sets the stage for future benefits. Together, the prospect of joblessness and the imperatives supplied by human capital theory keep young people compliant and coming back for more (Perlin, 2011: 128, 135).

\section{The distributed workforce}

In what industry insiders call "the distributed workforce", web companies auction off laborious one-time chores that workers then bid on or accept. Examples include Uber, which crowdsources taxi rides, TaskRabbit, which auctions off odd jobs (e.g., weeding, housecleaning), Mechanical Turk, which outsources online microtasks (e.g., tweets), and Postmates, which assigns courier services (e.g., delivering sandwiches, coffee, groceries). Again, a key disciplinary mechanism is the structure of the work itself. Companies using Amazon's online outsourcing marketplace, Mechanical Turk, pay workers anywhere from nothing, to virtual currency, to $\$ 2$ per Human Intelligence Task (HIT). Apart from the fact that workers are classified as independent contractors and are therefore not subject to minimum wage laws, companies are able to outsource for free because the rate of pay and access to plum jobs increases with the number of HITs under one's belt. An unpaid HIT is incentive enough to perform a task.

In other cases, the work is organised by smartphone apps. For example, Postmates, which bills itself as "Fedex within a city", offers customers an app called Get It Now, which they can download and use to have items delivered to them. Postmates broadcasts the job via smartphone to couriers, who must hit "accept" before anyone else does to win the job. The courier then has one hour to buy the goods with a company-issued debit card and deliver them. Because smartphones have GPS technology, employers can keep track of workers' 
whereabouts, while a timer on the phone ticks away the seconds.

Distributed workforce companies often construct a game-like environment. Reporting

on TaskRabbit, Wired Magazine writes, "To keep the rabbits scampering, the site employs some serious game mechanics. A leaderboard ranks the top runners, displaying the level that each has achieved and their average customer review" (Tsotsis, 2011). Another disciplinary mechanism is discursive: distributed workforce jobs are framed as middle-class positions that are flexible and entrepreneurial. Leah Busque, who started and runs TaskRabbit, says, "We are enabling micro-entrepreneurs to build their own business on top of TaskRabbit, to set their own schedules, specify how much they want to get paid, say what they are good at, and then incorporate the work into their lifestyle" (Stone, 2012: 1). On the "Become a TaskRabbit" page of the company's website, various testimonials suggest that workers have internalised the entrepreneurial spirit and flexibility articulated by the organisation.

\section{The transformation of work in the Turkish economy}

Although the roots of neo-liberalism in Turkey predate the Justice and Development Party (AKP) government, it has taken significant steps to transform the "ecology of employment" in Turkey in order to facilitate the institutionalisation of a new accumulation strategy that courts the needs of a burgeoning export-oriented private sector (YucesanOzdemir and Ozdemir, 2008: 100-117). Unlike the US, where market forces are at the forefront, in Turkey it is direct state involvement that primarily guides the trajectory of employment relations.

\section{Changes in Social Security Mechanisms}

In the wake of World War 2, Turkey created a highly fragmented and overburdened social security system; by the early 1980s, it could reach only about half of the population (Topak, 2012: 197-218). An “inegaliterian corporatist” welfare regime (Bugra and Adar, 2008) emerged when informal mechanisms emerged to complement the formal ones. These include family networks connecting migrant families to their relatives in rural areas, clientelist recruiting practices utilising ethnic and sectarian connections, and patronage relationships in which local political elites often turned a blind eye to illegal activities.

The dissolution of the agricultural sector and the forced relocation of the Kurdish population from eastern parts of the country intensified the migration from rural to urban areas throughout the 1980s and 1990s. This severely strained the capacity of the urban industrial sector to absorb the incoming workforce. Moreover, urban transformation programmes and the formalisation of the real estate market under the pressure of global capital made illegal housing on state land almost impossible. Traditional social protection mechanisms "have lost their significance as it has become increasingly difficult for [the new immigrants] to settle in the same neighbourhood with their family members and co-locals" (Bugra and Keyder, 2006: 220).

In response to the emerging crisis, the AKP government began implementing 
comprehensive social welfare reform in the areas of health, pensions and social assistance. ${ }^{4}$ These changes were deeply influenced by the neo-liberal paradigm centred on privatisation, marketisation and commodification of social services (Yucesan-Ozdemir and Ozdemir, 2008; Cosar and Yegenoglu, 2009). Any form of social support for able-bodied adults was to be conditional on participation in productive activity, since unconditional grants were believed to foster dependency. The government adopted policies to mobilise civil society, delegating the responsibility of addressing poverty and social exclusion to mostly religious charity organisations with close ties to local governments that were expected (and redesigned) to act as "charity brokers" (Bugra and Keyder, 2006: 224). Social welfare policies have often been implemented within the party's conservative framework, granting legal flexibility to loyal philanthropic organisations for collecting donations, and utilising patronage networks to compel the recipients of these services to its moral and cultural outlook (Kayaalp, 2015: 118). Moreover, the AKP has often encouraged "volunteer citizens" to assume the role of social workers and help those in need, which can be seen as yet another sign of the party's socially conservative neo-liberal agenda that aims to institute a social welfare model which minimises the role of the state in tackling poverty (Eroglu, 2013).

\section{Changes in Labour Legislation}

While the reorganisation of the social security system had a significant impact on the lives of wage-earners and their families, changes in the legal sphere of employment became an even more critical factor in their precarisation. In the 1980s and 1990s, Turkey had witnessed suppression of fundamental labour rights, sharp declines in wages and the expansion of the informal economy. But it was only under AKP rule since 2002 that critical steps were taken towards profoundly restructuring employment relations. The introduction of legal changes rendered employment relations more flexible, enforcing restrictions on the rights of public sector employees to organise, strike and bargain collectively. Privatisation and the accompanying surge in lay-offs in state-owned enterprises were followed by the withdrawal of employment-based entitlements, leaving workers increasingly at the mercy of the market.

The new labour law in 2003 (article 4857) was a milestone in instituting new practices. The law introduced language that makes it easier for companies to offer their employees fixedterm contracts, with significant limitations on the eligibility for pensions, health insurance and other benefits (Koc, 2006: 40-44). Under the new law, companies with less than thirty employees (an increase from ten) are not obligated to provide a legitimate reason, such as economic hardship or disciplinary issues, for the termination of a labour contract. According to a recent analysis, nearly 50 per cent of all workers in Turkey are no longer eligible for legal employment security under the new law (Oker, 2014). Moreover, businesses facing bankruptcy

\footnotetext{
${ }^{4}$ The extensive reform package included the establishment of universal health insurance managed under a single agency, the restructuring of social assistance and services in terms of eligibility and benefit schemes, the reform of the pension system by creating a single system and recalculating retirement age and benefits, and unifying existing separate social security schemes under one centralised Social Security Institution (Yakut-Cakar, 2007).
} 
can employ workers for short terms, during which they are not obligated to pay social security contributions. The employment contract can now be scripted to enable employers to easily outsource parts of their core and peripheral tasks, and implement more flexible hiring practices (Kutlu, 2012).

In 2011 a new set of regulations was introduced regarding the employment criteria for interns, overtime work, shared work, telework and work from home. Under the new legislation (article 6111), companies can now lease their employees to other companies for fixed terms up to eighteen months. During this time, workers receive their wages from the leasing company, and are not eligible for the benefits the hiring company offers to its own workers. The language of the legislation is ambiguous with respect to the number and duration of leasing, making it harder for workers to convert their temporary positions into permanent ones. In other words, article 6111 has transformed Turkey into a gig economy in utero.

As a result of these legal changes, the official number of workers in subcontractor firms increased from approximately 400000 in 2002 to more than 1.6 million in 2012 (SSI, 2012). The rise in the number of temporary workers from 1988 to 2010, and especially in the last decade, is no less remarkable (see Goztepe, 2012). The government is reportedly working on a new draft bill which further curtails job security for public servants, and subjects them to performance criteria in order "to be able to distinguish 'efficient' employees from the 'inefficient" (T24.com, 2012). More recently, the government announced that it was preparing to propose new legislation that would expand the scope of subcontracting relationships in various sectors of the economy (Alp, 2014). All these steps reveal a clear move towards instituting a legal framework which expands flexible, temporary and insecure employment relations.

\section{Governing through tiered citizenship regimes}

Although the US and Turkey experience neo-liberalism in distinct ways, in both cases precarisation processes become a form of social discipline and a technology for governing disfranchised citizens. What seems to be taking place in both societies is a profound change in the perception of the meaning of life and work, what to expect from the future, and the state's responsibility in the welfare of its citizens. What we have discussed so far reveals that social citizenship is still strongly tied to wage employment in the US, yet the formal sector itself is being supplanted by a gig economy that can only offer a highly precarious wage-earning experience. The commodification of social services and the erosion of labour rights in Turkey at the hands of the state bring about a similar outcome, where wage-earners become increasingly dependent on the labour market despite the scarcity in stable and secure jobs in the formal economy.

While the situation of interns and task rabbits is the result of the neo-liberal state's reorientation to the market, the story does not end there. The dual nature of the neo-liberal state is fully exposed when groups with insufficient social and cultural capital to compete at the margins of the formal wage sector, or those whose voice is silenced to prevent the disclosure of their deteriorating rights and working conditions, are subject to aggressive intervention by the same state. In other words, the emerging citizenship regimes are not simply 
determined by unfettered market forces or by the state's market orientation, but also by its coercive practices, which often operate in the background.

One primary form of intervention in the US is mass incarceration. Loïc Wacquant (2002, 2009) links this particularly racialised governance practice to neo-liberalism. For him, mass incarceration emerges as a technology for managing this unmarketable sector of the surplus population, which he refers to as "the precarious and deproletarianised fractions of the black working class" (Wacquant, 2009: xvi). Gilmore (2007: 111-112) corroborates this claim in the case of California where the incarcerated population comprises growing numbers of the precariously employed: "The percentage of prisoners who worked six months or longer for the same employer immediately before being taken into custody has declined, from 54.5 percent in 1982 to 44 percent in 2000". To be clear, then, those sectors of the population who are disciplined via mass incarceration are both those who lack social capital to gain entry into the precariat (as in Wacquant), and those who give up in favour of extra-legal forms of survival (as in Gilmore).

Gilmore's work is a fitting segue to another aggressive technique of managing the surplus population under neo-liberalism, for among her core observations is that Latinos have surpassed blacks as the plurality of California inmates. This, she argues, is due to the fact that Latinos, stereotypically cheap labour though they are, have become increasingly disposable on the lower rungs of the formal-sector ladder (Gilmore, 2007: 111). Drawing on this observation and the work of Tanya Golash-Boza (2012), we argue that the neo-liberal state manages Latinos in the surplus population by 1) deporting immigrants en masse; and 2) sustaining, through draconian policy, a cheap deportable labour force in selective sectors of the economy. In this respect, mass deportation is intimately connected to precarious work in certain lowwage industries. De Genova (2005) argues that current immigration policy "serves to create a deportable migrant labour force", which ensures that some migrants will be deported but the majority will remain as socially marginal and vulnerable workers (cited in Golash-Boza, 2012: 149).

The management of the immigrant surplus population through both deportation and deportability is further expanded by related policies (most famously by Deferred Action for Childhood Arrivals, or DACA) that generate and keep tabs on "liminally legal" immigrants: those who are legally allowed to work in the United States but are unable to access political and social citizenship rights (Menjivar, 2006; Cebulko, 2013). In this way, the neo-liberal state "creates and recreates an excluded population and ensures its vulnerability and precariousness by blurring the boundaries of legality and illegality to create grey areas of incertitude" (Menjivar, 2006: 1002).

In Turkey, in order to maintain stability and order among discontented populations, the AKP government not only carries out social redistribution through singling out "loyal recipients" according to their ideological and religious orientation, but it also actively defines the "virtuous worker-citizen" through imposing an authoritarian and socially conservative agenda, which is best typified by its dealings with strikes and workplace accidents.

For more than a decade now, the AKP government has framed strikes as "irresponsible", "irrational" and a "threat" to national unity, propped up by "foreign powers". 
This strong nationalist and religious rhetoric brands protesting workers as "un-citizens", and presents them as puppets of unpatriotic and marginal political forces, or as moochers on the national patrimony. The nationalist ideology in this context serves as an authoritative vehicle to impose the market logic on workers by demonising their collective rights and presenting them as contrary to "national interests" (Altan-Olcay, 2011: 62). This image of dissenting workers as a lazy, undeserving mob exploiting the public's wealth is often used to put them against "the people", the nation of "desirable worker-citizens" who are self-reliant, industrious, obedient and grateful. Here, a "two-nation project" emerges in which "an entrepreneur, active, responsible and hard-working citizen is clashed with irresponsible, selfish, and lazy outsiders, therefore drawing the boundary between inside and outside, between us and them" (Yedekci, n.d.: 11-12).

One such instance was in 2010 when the privatisation of TEKEL, the former state-run alcohol and tobacco producer, led to the dismissal of hundreds of workers, for whom the government wanted to introduce a temporary status with severe pay cuts and diminished benefits. The workers, who initiated a 78-day protest campaign against the proposal, were dismissed by the then prime minister Tayyip Erdogan as "instruments of opposition parties and marginal organizations" (Today's Zaman, 2010). He depicted the protesting workers as "unneeded, redundant people", accusing them of "infringing on [his] orphans' rights". By doing so, Erdogan was drawing a clear line between the "deserving citizens" and "undeserving and greedy individuals", reminding the latter that they were bordering on becoming "criminals" for working against the interests of the nation. The violence towards the workers was not always symbolic: they were pepper-sprayed, dispersed with water cannons and harshly beaten by the police (BBC Turkish Service, 2010).

Another example of the government's authoritarianism and social conservatism occurred in May 2014 when 301 miners were killed in an explosion in a coal mine in Soma, a small town in Western Turkey. Before the accident, the owner of the mine, which was privatised in 2005, reportedly took pride in lowering the cost of production from $\$ 120$ per ton to approximately $\$ 20$ after taking over the company (Yeldan, 2014). Motivated by high returns, subcontractors undertaking various critical tasks in the mine did not pay sufficient attention to safety regulations (HaberVS.com, 2014). The resulting unsafe working conditions deteriorated even further when the government rejected a number of parliamentary inquiries into the company's repeated failure to pass safety inspections - the most recent of which was just two weeks before the explosion (Verstraete, 2014). ${ }^{5}$

The government's response to the tragedy was emblematic of its style in handling workrelated issues. Right after the incident, Erdogan argued that accidents like this one were takdiri ilabi (divine will) and happened all the time. He reminded the public that it was in the nature

\footnotetext{
${ }^{5}$ While a tragic incident of such proportions is rare, Turkey has the highest rate of worker deaths in the world (Eissenstat, 2014). The country's poor record of industrial safety has in fact been a part of Turkey's recent "impressive" economic growth under AKP rule. According to the International Labour Organisation, a total of 12686 workers lost their lives due to work accidents in Turkey between 2000 and 2012 (Yildiz, 2014).
} 
of this particular profession that accidents were unavoidable and unforeseeable (Yildiz, 2014). The choice of a divine cosmology to describe the incident is not difficult to spot as a distraction from a sober critique of insufficient safety measures in the mine. But going even further, the government deployed eighty imams (Muslim clerics) from around the province to defuse public discontent. These imams were later joined - according to some reports - by another 500, along with only ten psychologists (Tremblay, 2014). While it is not unusual to have imams pray for the deceased and to give sermons to their families, these imams were reported to have also advised the locals not to protest, but to remain calm and listen to the elders and leaders of the country (Tremblay, 2014). They were, in other words, officially charged to convince the public that what had happened was an unavoidable accident and that death was the unquestionable destiny of miners. In this way, the victims of the explosion were framed as the collateral damage of economic progress, thereby exonerating the government from any wrongdoing (Yildiz, 2014).

When these socially conservative messages failed to stave off public anger, the government resorted to harsher tactics, such as cordoning off the town to block the entry of civil society organisations and journalists. AKP delegations, including Erdogan himself, were met with angry crowds when they visited the town. Protestors - many of them relatives and friends of the victims - were dispersed by tear gas and water cannons, beaten by the police, and arrested, not just in Soma but also in other parts of the country (Eissenstat, 2014; Links, 2014).

\section{Conclusion}

In this paper, we have attempted to theorise what happens when there is "a radical dissociation between 'work' as experienced by the post-Fordist labour force, and a system of social citizenship still rooted in the Fordist concept of work as a full-time, life-long experience" (De Giorgi, 2007: 15). For a growing number of people, productive activities are no longer a gateway to economic inclusion and full social integration. Yet, the puzzle of governability under neo-liberalism is complex and can only be addressed adequately if a two-fold analysis of the transformation of work and citizenship is taken into account. By bringing together macro-historical studies of neo-liberalism, the governmentality literature, and Marxist theories of state authoritarianism, our research reveals that a dual movement of simultaneous reorientation and intervention by the neo-liberal state is taking place in distinct yet parallel ways in the US and Turkey. In other words, the processes of dissociation and exclusion that emerge as a result of the changes in work and employment structures are handled differently in these societies. In the United States, the transformation of the work-citizenship nexus has led to the reorganisation of labour relations through the precarious nature of emerging servicesector jobs such as internships and crowdsourcing, which lack state-backed social protection. When this strategy of state reorientation falls short in managing some sectors of the society, a heavy-handed intervention in the form of incarceration and deportation occurs. In Turkey, on the other hand, state-led changes in social security mechanisms and labour law aim to render market relations primary in determining the fate of wage-earners. This is coupled with a strong 
authoritarian and socially conservative rhetoric that brand dissidents as "un-citizens" or mystifies the work process as part of an unquestionable, divine order. Though distinct in terms of methods and consequences in each case, the dual character of the neo-liberal state in Turkey and the United States produces tiered citizenship regimes to contain the growing ranks of the dispossessed under neo-liberalism.

\section{REFERENCES}

Alp, A. (2014) Milyonlarca Çalışana Büyük Şok [Big Shock to Millions of Employees]. Hurriyet Daily, 28 May 2014. Available online at http://www.hurriyet.com.tr/ekonomi/ 26491509.asp (accessed 4 August 2014).

Altan-Olcay, O. (2011) Reframing the Ideal Citizen in Turkey: National Belonging and Economic Success in the Era of Neoliberalism. New Perspectives on Turkey, 44 (Spring): 4172.

Andersen, J.G. and P.H. Jensen (2002) Citizenship, Changing Labour Markets and Welfare Policies: An Introduction. In Changing Labour Markets, Welfare Policies and Citizenship, edited by J.G. Andersen and P.H. Jensen. Bristol: Policy Press.

Appelbaum, B. and R. Gebeloff (2012) Even Critics of Safety Net Increasingly Depend on it. New York Times, 11 February 2012. Available online at http://www.nytimes.com/2012/ 02/12/us/even-critics-of-safety-net-increasingly-depend-on-it.html? r=3\&pagewanted $\equiv 1 \&$ (accessed 23 October 2012).

Barchiesi, F. (2011) Precarious Liberation: Workers, the State, and Contested Social Citizenship in Postapartheid South Africa. Albany: SUNY Press.

BBC Turkish Service (2010) Tekel işçilerine Ankara'da sert polis müdahalesi [Harsh Police Intervention to Tekel Workers in Ankara], 2 April 2010. Available online at http://www.bbc.co.uk/turkce/haberler/2010/04/100401 tekel.shtml (accessed 18 June 2014).

Beck, U. (2000) The Brave New World of Work. Cambridge: Polity.

Beneria, L. (2010) Globalization and Gender: Women's Labour in the Global Economy. In Globalization in the 21st Century: Labour, Capital, and the State on a World Scale, edited by B. Berberoglu. New York: Palgrave.

Bugra, A. and S. Adar (2008) Social Policy Change in Countries without Mature Welfare States: The Case of Turkey. New Perspectives on Turkey, 38 (Spring): 83-106.

Bugra, A. and C. Keyder. (2006) The Turkish Welfare Regime in Transformation. Journal of European Social Policy, 16(3): 211-228.

Cebulko, K. (2013) Documented, Undocumented, and Liminally Legal: Legal Status During the Transition to Adulthood for 1.5-Generation Brazilian Immigrants. Sociology Quarterly, 55: 143-167.

Collins, J. (2013) The Birth of Biosecurity? New Left Review, 81 (May-June): 145-153.

Congressional Budget Office (2011) Trends in the Distribution of Household Income 
Between 1979 and 2007. Available online at http://www.cbo.gov/publication/42729 (accessed 23 October 2012).

Cosar, S. and M. Yegenoglu (2009) The Neoliberal Restructuring of Turkey's Social Security System. Monthly Review, 60 (11, April). Available online at http://monthlyreview.org/2009/04/01/the-neoliberal-restructuring-of-turkeys-socialsecurity-system (accessed 9 September 2016).

Crouch, C. (2011) The Strange Non-death of Neo-liberalism. Cambridge: Polity.

De Giorgi, A. (2007) Toward a Political Economy of Post-Fordist Punishment. Critical Criminology, 15: 243-265.

Dedeoglu, S. (2008) Women Workers in Turkey: Global Industrial Production in Istanbul. London and New York: Tauris.

Durak, Y. (2011) Emegin Tevekkulu [The Submission of Labour]. Istanbul: Iletisim.

Ehrenreich, B. (2011) Nickel and Dimed: On (Not) Getting by in America. New York: Picador.

Eissenstat, H. (2014) 3 Reasons Amnesty is Concerned about Turkey's Mining Disaster. Amnesty International USA. Available online at http://blog.amnestyusa.org/europe/3reasons-amnesty-is-concerned-about-turkeys-mining-disaster (accessed 22 July 2014).

Eroglu, D. (2013) Sosyal Refah Devletinden Gonullu Vatandas Kalkinmaciligina [From the Welfare State to Volunteer Citizen Developmentalism]. Birikim - Guncel Yazılar, 4 May 2013. Available online at http://www.birikimdergisi.com/birikim/makale.aspx?mid $=943 \&$ makale $=$ Sosyal + Refah + Devletinden $+\% 22 \mathrm{G} \% \mathrm{~F} 6 \mathrm{n} \% \mathrm{FCll} \% \mathrm{FC}+\mathrm{Vatanda} \% \mathrm{FE} \% 2$ 2+Kalk $\%$ FDnmac $\%$ FDl $\%$ F0\%FDna (accessed 5 August 2014).

Esping-Andersen, G. (1990) Three Worlds of Welfare Capitalism. Cambridge: Polity.

Foucault, M. (1991 [1979]) Governmentality. In The Foucault Effect, edited by G. Burchell, C. Gordon and P. Miller. Chicago: University of Chicago Press.

Fraser, J.A. (2002) White Collar Sweatshop: The Deterioration of Work and Its Reward in Corporate America. New York: Norton.

Gilmore, R.W. (2007) Golden Gulag: Prisons, Surplus, Crisis, and Opposition in Globalizing California. Berkeley and Los Angeles: University of California Press.

Golash-Boza, T. (2012) Immigration Nation: Raids, Detentions, and Deportations. Boulder and London: Paradigm.

Gopal, M. (2007) Revisiting Gendered Home-based Work in the Context of Reforms. In Labour, Globalization and the State, edited by D. Banerjee and M. Goldfield. Oxford and New York: Routledge.

Goztepe, O. (2012) Yeni Donemin Satirbaslari [Headlines of the New Era]. In Guvencesizlestirme [Insecuritization], edited by O. Goztepe. Ankara: Notabene.

HaberVS.com (2014) Soma'daki faciaya, aşırı üretim isteği davetiye çıkardı [Overproduction crave caused the disaster in Soma]. Available online at http://www.habervesaire.com/site/tool/popup/news print.php?id=2709 (accessed 22 July 2014). 
Hall, S., C. Critcher, T. Jefferson, J. Clarke and B. Roberts (1978) Policing the Crisis: Mugging, the State, and Law and Order. London: Macmillan.

Hanser, A. (2007) A Tale of Two Sales Floors: Changing Service-Work Regimes in China. In Working in China: Labour and Workplace Transformations, edited by C.K. Lee. London: Routledge.

Harvey, D. (2007) Neoliberalism as Creative Destruction. Annals of the American Academy of Political and Social Science, 610: 22-44.

Head, S. (2003) The New Ruthless Economy: Work and Power in the Digital Age. New York: Oxford University Press.

Heller, P. (2000) The Labour of Development: Workers and the Transformation of Capitalism in Kerala, India. Ithaca: Cornell University Press.

Ivry, B., B. Keoun and P. Kuntz (2011) Secret Fed Loans Gave Banks \$13 Billion Undisclosed to Congress. Bloomberg Markets Magazine, 27 November 2011. Available online at http://www.bloomberg.com/news/2011-11-28/secret-fed-loans-undisclosed-tocongress-gave-banks-13-billion-in-income.html (accessed 23 October 2011).

Jessop, B. (2002) The Future of the Capitalist State. Cambridge, UK: Polity.

Juravich, T. (2009) At the Altar of the Bottom Line: The Degradation of Work in the 21st Century. Amherst: University of Massachusetts Press.

Kalleberg, A. (2011) Good Jobs, Bad Jobs: The Rise of Polarized and Precarious Employment Systems in the United States, 1970s-2000s. New York: Russell Sage Foundation.

Kayaalp, E. (2015). Remaking Politics, Markets and Citizens in Turkey. London and New Delhi: Bloomsbury.

Koc, Y. (2006) AKP Iscilere Nasil Zarar Veriyor [How does the AKP Harm Workers]? Istanbul: Kaynak Yayinlari.

Kutlu, D. (2012) Turkiye Isgucu Piyasasinda Guncel Gelismeler ve Guvencesizlestirme Oruntuleri [Contemporary Developments in the Turkish Labour Market and Patterns of Insecuritization]. In Guvencesizlestirme [Insecuritization], edited by O. Goztepe. Ankara: Notabene.

Links, J. (2014) The Soma tragedy: Kadere karş1 / Against Fate. LeftEast, 17 May 2014. Available online at http://www.criticatac.ro/lefteast/the-soma-tragedy-kadere-karsiagainst-fate (accessed 9 September 2015).

Lordon, F. (2010) Capitalisme, Désir et Servitude: Marx et Spinoz̧a. Paris: La fabrique éditions.

Luhby, T. (2012) Welfare Spending Cut in Half Since Reform. CNN Money, 9 August 2012. Available online at http://money.cnn.com/2012/08/09/news/economy/welfarereform/index.htm (accessed 23 October 2012).

MacLeod, J. (2008) Ain't No Makin' It: Aspirations and Attainment in a Low-Income Neighborbood. Boulder, CO: Westview.

Marvit, M.Z. (2014) How Crowdworkers Became the Ghosts in the Digital Machine. The Nation, 5 February 2014. Available online at: http://www.thenation.com/article/178241/ 
how-crowdworkers-became-ghosts-digital-machine?page=full\# (accessed 13 February 2014).

McMichael, P. (2012) Development and Social Change. Thousand Oaks, CA: Sage.

Menjivar, C. (2006) Liminal Legality: Salvadoran and Guatemalan Immigrants' Lives in the United States. American Journal of Sociology, 111(4): 999-1037.

National Association of Colleges and Employers (NACE) (2012) 2012 Internship and Co-op Survey. Available online at www.naceweb.org (accessed 21 October 2012).

Oker, I. (2014) Reform in Labour Code in Turkey: Changing the Nature of Labour Market? Research Turkey, 3(9): 16-43. Available online at http://researchturkey.org/?p=6831 (accessed 12 December 2014).

Ong, A. (1999) Flexible Citizenship: The Cultural Logics of Transnationality. Durham: Duke University Press.

Ong, A. (2006) Neoliberalism as Exception: Mutations in Citizenship and Sovereignty. Durham: Duke University Press.

Perlin, R. (2011) Intern Nation: How to Earn Nothing and Learn Little in the Brave New Economy. New York: Verso.

Postmates. [n.d.] [Online] Available at: http://postmates.com/apply (accessed 14 January 2014).

Poulantzas, N. (1978) State, Power, Socialism. New York: Verso.

Rocha, E.P.R. (2004) Effects of Globalization on the Workers of the Electronics Cluster in Jalisco, Mexico. Research in the Sociology of Work, 13: 125-140.

Root, A. (2007) Market Citizenship: Experiments in Democracy. London and Thousand Oaks, CA: Sage.

Rose, N. (1999) Powers of Freedom: Reframing Political Thought. Cambridge: Cambridge University Press.

Rose, N. (2007) Politics of Life Itself: Biomedicine, Power, and Subjectivity in the Twenty-First Century. Princeton: Princeton University Press.

Roy, S. (2007) Unorganized Manufacturing, Flexible Labour and the "Low Road". In Labour, Globalization and the State, edited by D. Banerjee and M. Goldfield. Oxford and New York: Routledge.

Sachs, A. (2011) Intern Nation. Time, 12 September 2011. Available online at http://www.time.com/time/magazine/article/0,9171,2091366,00.html (accessed 21 October 2012).

Sainz, J.P.R. (2000) From the Finca to the Maquila: Labour and Capitalist Development in Central America. Boulder, CO: Westview.

Schor, J. (1993) The Overworked American. New York: Basic Books.

Sennett, R. (2000) The Corrosion of Character: The Personal Consequences of Work in the New Capitalism. New York: Norton. 
Smith, V. (1997) New Forms of Work Organization. Annual Review of Sociology, 23: 315-339.

Social Security Institution of the Republic of Turkey (SSI) (2012) Response to the Parliamentary Motion (no. 7/9123) by Istanbul MP Mahmut Tanal, 19 September 2012. Available online at http://www2.tbmm.gov.tr/d24/7/7-9123c.pdf (accessed 4 August 2014).

Somers, M.R. (2001) Romancing the Market, Reviling the State: Historicizing Liberalism, Privatization, and the Competing Claims to Civil Society. In Citizenship, Markets, and the State, edited by C. Crouch, K. Eder and D. Tambini. Oxford and New York: Oxford University Press.

Standing, G. (1999) Global Labour Flexibility: Seeking Distributive Justice. New York: St. Martin's.

Standing, G. (2009) Work After Globalization: Building Occupational Citizenship. Cheltenham, UK and Northhampton, MA: Edward Elgar.

Standing, G. (2011) The Precariat. London: Bloomsbury Academic.

Stone, B. (2012) My Life as a Task Rabbit. Bloomberg Business Week, 13 September 2012. Available online at http://www.businessweek.com/articles/2012-09-13/my-life-as-ataskrabbit (accessed 21 October 2012).

T24.com (2012) Memura Isguvencesi Kalkiyor! [Job Security for Public Servants is being abolished!]. Available online at http://t24.com.tr/haber/memura-is-guvencesikalkiyor,214791 (accessed 4 August 2014).

TaskRabbit. [n.d.] Become a TaskRabbit. Available online at https://www.taskrabbit.com/ become-a-taskrabbit (accessed 15 January 2014).

Tilly, C. (1996) Half A Job: Bad and Good Part-Time Jobs in a Changing Labour Market. Philadelphia: Temple University Press.

Today's Zaman (2010) PM Erdogan: "We assumed positive stance towards TEKEL workers". Available online at https://www.todayszaman.com/newsDetail openPrintPage.action ?newsId=199342 (accessed 5 August 2014).

Topak, O. (2012) Refah Devleti ve Kapitalizm [Welfare State and Capitalism]. Istanbul: Iletisim.

Tremblay, P. (2014) AKP advice to Soma: Don't protest, just pray. Al-Monitor, 19 May 2014. Available online at: http://www.al-monitor.com/pulse/originals/2014/05/turkey-somaminedisaster-akp-prayer-advice.html (accessed 22 July 2014).

Tsotsis, A. (2011). TaskRabbit Turns Grunt Work into a Game. Wired Magazine. Available online at http://www.wired.com/magazine/2011/07/mf taskrabbit (accessed 23 October 2012).

Verstraete, P. (2014) Turkey coalmine disaster: accident or murder? Roar Magazine, 14 May 2014. Available online at http://roarmag.org/2014/05/turkey-soma-coalmine-disaster (accessed 22 July 2014).

Wacquant, L. (2002) From Slavery to Mass Incarceration: Rethinking the Race Question in the U.S. New Left Review, 13 (Jan-Feb): 41-60.

Wacquant, L. (2009) Punishing the Poor: The Neoliberal Government of Social Insecurity. Durham and 
London: Duke University Press.

Yakut-Cakar, B. (2007) Turkey. In Social Policy and International Interventions in South East Europe, edited by B. Deacon and P. Stubbs. Cheltenham and Northampton, MA: Edward Elgar.

Yedekci, A. [n.d.] Governing Through Insecurities: Constituting the Neoliberal Citizen in Turkey, the Case of Tekel Workers' Resistance. Available online at https://www.academia.edu/1619199/Governing Through Insecurities Constituting t he Neoliberal Citizen in Turkey the Case of Tekel Workers Resistance (accessed 5 August 2014).

Yeldan, E. (2014) The Tragedy of the Soma Mine-Workers. Triple Crisis, 15 May 2014. Available online at http://triplecrisis.com/the-tragedy-of-the-soma-mine-workers/print (accessed 22 July 2014).

Yildiz, E. (2014) On Erdogan's “Ordinary Things": The Soma Massacre, the Spine Tower, and the Corporate-State's Fitrat in Turkey. Jadalliya, 18 May 2014. Available online at http://www.jadaliyya.com/pages/index/17742/on-erdogan $\% \mathrm{E} 2 \% 80 \% 99$ s$\% \mathrm{E} 2 \% 80 \% 98$ ordinary-things $\% \mathrm{E} 2 \% 80 \% 99$ the-soma-massacre-t (accessed 22 July 2014).

Yucesan-Ozdemir, G. and M. Ozdemir (2008) Sermayenin Adaleti [The Justice of Capital]. Ankara: Dipnot.

\section{BIOGRAPHICAL NOTES}

KAAn Agartan is Assistant Professor of Sociology at Framingham State University. His authored and co-authored articles and reviews have appeared in Journal of Balkan and Near Eastern Studies, Sociology Compass, European Journal of Turkish Studies, Journal of International Affairs, New Perspectives on Turkey, and Capital and Class. He is the co-editor of Reading Karl Polanyi for the Twenty-first Century: Market Economy as a Political Project (Palgrave, 2007). [E-mail: kagartan@framingham.edu]

CEDRIC DE LEON is Chair and Associate Professor of Sociology at Providence College. He is the author or co-editor of three books: The Origins of Right to Work (Cornell, 2015), Building Blocs with Manali Desai and Cihan Tugal (Stanford, 2015), and Party and Society (Polity, 2014). His research centres on the contradictions of liberal democracy, especially with respect to labour, race and party politics. [E-mail: cdeleon@providence.edu] 